Revista de

Direito Econômico e

Socioambiental

ISSN 2179-8214

Licenciado sob uma Licença Creative Commons

(c) (†) (8)

\title{
REVISTA DE DIREITO ECONÔMICO E SOCIOAMBIENTAL
}

vol. 9 | n. 3 | setembro/dezembro 2018 | ISSN 2179-8214

Periodicidade quadrimestral | www.pucpr.br/direitoeconomico

Curitiba | Programa de Pós-Graduação em Direito da PUCPR 


\title{
Trabalho terceirizado: sobre a precarização das condições de trabalho a partir da Lei de Terceirização e da Reforma Trabalhista
}

\section{Outsourced Labor: on the precariousness of labor conditions after the Outsourcing Act and the Labor Reform}

\author{
Josué Mastrodi* \\ Pontifícia Universidade Católica de Campinas (Brasil) \\ mastrodi@puc-campinas.edu.br \\ Thaís Calsoni Corsi ${ }^{* *}$ \\ Pontifícia Universidade Católica de Campinas (Brasil) \\ thaiscalsonicorsi@gmail.com
}

Recebido: $24 / 08 / 2017$

Received: 08/24/2017
Aprovado: $16 / 08 / 2018$

Approved: 08/16/2018

Como citar este artigo/How to cite this article: MASTRODI, Josué; CORSI, Thaís Calsoni. Trabalho terceirazado: sobre a precarização das condições de trabalho a partir da Lei da Terceirização e da Reforma Trabalhista. Revista de Direito Econômico e Socioambiental, Curitiba, v. 9, n. 3, p. 243-270, set./dez. 2018. doi: 10.7213/rev.dir.econ.soc.v9i3.18318.

\footnotetext{
* Professor dos cursos de Direito e pós-graduação stricto sensu em Sustentabilidade da Pontifícia Universidade Católica de Campinas (Campinas-SP, Brasil). Doutor em Filosofia e Teoria Geral do Direito pela Universidade de São Paulo. E-mail: mastrodi@puc-campinas.edu.br.

** Bacharela em Direito pela Pontifícia Universidade Católica de Campinas (Campinas-SP, Brasil). E-mail: thaiscalsonicorsi@gmail.com.
} 


\section{Resumo}

Tratamos, nesta pesquisa, da terceirização como técnica de fragmentação da cadeia produtiva para a redução de gastos com a mão de obra às custas da precarização do trabalho. A Lei n. 13.429, de 31 de março de 2017, viabiliza a terceirização das atividades-fim, algo que, pela sistemática anteriormente vigente de proteção do trabalhador, em especial por força da Súmula 331 do Tribunal Superior do Trabalho, se mostrava completamente vedado. Porém, em que pese a terceirização da atividade-fim estar legalmente autorizada, entendemos que ainda há formas jurídicas de proteção do trabalhador contra mais essa precarização. A atual estrutura de proteção sindical deveria englobar, na representação do sindicato, todos os trabalhadores envolvidos na atividade-fim, inclusive os eventuais terceirizados. Situação em que até poderia haver terceirização dos serviços, mas a estrutura de proteção do Direito Coletivo do Trabalho, em especial por meio da atuação sindical, deve impor remuneração isonômica aos terceirizados, na mesma medida da remuneração dos empregados diretos. Como a terceirização, para ser realizada, depende necessariamente da redução dos custos de produção, a isonomia no tratamento dos trabalhadores terceirizados envolvidos na mesma atividade-fim dos empregados diretos torna a mudança legislativa trazida pela Lei $n$. 13.429 totalmente inócua. Ainda que a Reforma Trabalhista tenha criado novas condições de degradação do trabalho por reduzir ou eliminar direitos em vigor desde a edição da Consolidação das Leis do Trabalho em 1943, concluímos que o Direito Coletivo ainda mantém alguma proteção em favor dos terceirizados.

Palavras-chave: precarização do trabalho; tereceirzação da atividade-fim; enquadramento sindical do terceirizado; reforma trabalhista; Lei no 13.429/2017.

\section{Abstract}

We address, in this research, the issue of outsourcing as a technique of fragmentation of the production chain by maximizing profits and reducing expenses with workforce due to lessening legal protection to employees. The Act n. 13.429 of March 31th, 2017, has allowed outsourcing of core activities in Brazil, unlikely the current system of labor protection, in particular by virtue of Precedent 331 of Brazilian Superior Labor Court. However, although the outsourcing of core activities became lawful, we have considered that there are still legal forms of protecting labor relations against this new precariousness. The current structure of Union protection would encompass all workers involved in the core activities, which should include the outsourced. Law would allow outsourcing of core activities, but the protection structure of Collective Labor Law, especially by means of Unionist practices, should impose isonomic compensation to outsourced employees as if they were direct employees. As outsourcing, to be processed, necessarily depends on the reduction of production costs, the equal treatment to outsourced workers engaged in the same core activities driven by direct employees would make the legislative changes proposed by the Act n. 13.429 totally innocuous. Although the Labor Reform has created new conditions for labor's degradation by reducing or eliminating rights 
that were in force since the Consolidation of Brazilian Labor Laws edition in 1943, we conclude that Collective Law can still protect the outsourced workforce.

Keywords: precariousness of labor relations; outsourcing of core activities; union framework of outsourced employees; labor reform; Act n. 13.429/2017.

\section{Sumário}

1. Introdução. 2. O Direito do Trabalho e a relação de emprego. 2.1. A Reforma Trabalhista trazida pela Lei n. 13.467 de 13 de julho de 2017: fortalecimento da relativização das normas protetivas do trabalhador. 2.2. O fenômeno da terceirização nos contratos de trabalho. 2.3. As distinções entre atividades-meio e atividades-fim. 3. A precarização do trabalho: aumento da produtividade versus redução de custos. 4. Normatização da Terceirização: Súmula 331 do Tribunal Superior do Trabalho e a Lei n. 13.429/2017. 5. As principais inovações da Lei $n$. 13.429/2017. 6. A questão da representação e atuação sindicais do terceirizado no atividadefim. 7. O sindicato poderá negociar a redução de direitos: mas isso só é válido para trabalhadores associados e não para toda a categoria. 8. A negociação coletiva pela qual direitos são suprimidos só será válida se impuser, em troca, que direitos com valor equivalente sejam conquistados. 9. A Reforma Trabalhista não tem como suprimir direitos e garantias constitucionais. 10. Considerações finais. Referências.

\section{Introdução}

A terceirização, assim entendida como modelo de sistematização da produção capitalista, surgiu no Brasil, no século XIX, principalmente, com as indústrias automobilística e têxtil, mas só se consolidou na década de 1980, quando expressou, de forma definitiva, uma estrutura por meio da qual certas atividades empresariais, que antes eram realizadas internamente, passaram a ser transferidas para outras empresas.

Em virtude da ausência de normatividade própria que disciplinasse o instituto da terceirização, o Tribunal Superior do Trabalho (TST) viu a necessidade de se posicionar frente às inúmeras demandas que chegavam para seu julgamento. Ao tratar da terceirização, o TST a legitimou, por meio da edição da Súmula 331, de 21 de dezembro de 1983, que se revelou uma solução imediatista e despida dos valores estabelecidos pelo Direito do Trabalho, pois autorizou a terceirização de quaisquer atividades-meio.

A terceirização de mão de obra, que já encontrava legitimação pela Súmula 331 do TST, sofreu regulamentação pelo Poder Legislativo por meio da aprovação da Lei n. 13.429, de 31 de março de 2017, que, por sua vez, 
alterou a Lei n. 6.019, de 3 de janeiro de 1974, que dispõe sobre o trabalho temporário nas empresas e estabelece diretrizes no tocante à terceirização.

A Lei n. 13.429 amplia e vulgariza, de forma arriscada, as hipóteses de terceirização, visto que a abertura a quaisquer atividades, inclusive para as atividades-fim, possibilita a delegação, pela empresa tomadora do serviço terceirizado, de praticamente toda sua atividade produtiva. Se os trabalhadores terceirizados não tiverem acesso às mesmas condições de trabalho dos trabalhadores não-terceirizados, isso tende a incentivar ainda mais a relativização da legislação trabalhista protetiva do trabalhador, que é a parte mais vulnerável da relação laboral.

Destacamos, também, a questão da representação e da atuação sindical do empregado terceirizado a exercer atividade-fim, hipótese agora prevista pela Lei n. 13.429/2017. Ora, se ao sindicato da categoria incumbe a representação de todos os trabalhadores que desempenham suas funções na atividade-fim da tomadora de serviços, essa representação também não deveria incidir sobre quaisquer terceirizados no exercício dessa atividadefim? Ao que tudo indica, a reposta é afirmativa a esta questão e, assim, a representação sindical abrangeria tais trabalhadores terceirizados no âmbito de sua categoria profissional.

Tendo em vista o crescimento do uso da terceirização no mundo contemporâneo e considerando a proteção ao trabalhador e a valorização do trabalho, consagradas pelo ordenamento jurídico pátrio, nossa pesquisa pretende enfrentar as seguintes questões: Com a aprovação e vigência da Lei n. 13.429/2017, que permite a ampliação das práticas de terceirização quais os seus impactos e em que medida contribui para intensificar a precarização do trabalho? E, com essa autorização legislativa, a atual estrutura de proteção do trabalhador por meio do Direito Coletivo do Trabalho, em especial por meio da proteção sindical, é suficiente para impedir a precarização do trabalho exercido na atividade-fim?

Parece-nos que a saída para frear a precarização das condições de trabalho na terceirização seria a proibição de tratamento distinto entre trabalhadores terceirizados e não-terceirizados, algo que não foi tratado pela Reforma Trabalhista, objetivando ao cumprimento pleno de todas as garantias constitucionais e trabalhistas acerca do trabalhador.

Para o desenvolvimento deste estudo, pretendemos compreender o intuito da criação do Direito do Trabalho e quais as relações por ele regidas, tendo em vista que o fenômeno da terceirização envolve, além da relação 
contratual de natureza comercial (entre as pessoas jurídicas), a relação de emprego (entre o trabalhador e a tomadora de serviços).

Ato contínuo, serão analisados os acontecimentos que deram origem à terceirização no mundo e no Brasil, e como a Justiça do Trabalho se posiciona sobre o tema, a partir da vigência da nova Lei n. 13.429/2017 e das modificações nas relações laborais oriundas da Reforma Trabalhista, considerando que se trata de prática que vem sendo muito difundida pelos empresários como forma de reduzir despesas com a folha de pagamento.

Nesse sentido, buscamos demonstrar que a precarização do trabalho deriva de decisões de ordem puramente econômica, visando ao aumento da produtividade empresarial e à redução de custos dos fatores de produção, considerando as mudanças ocorridas nas condições de trabalho, em especial quanto à jornada de trabalho e ao ganho salarial, e também na atuação sindical.

Mediante o estudo tanto da Súmula 331 do Tribunal Superior do Trabalho (TST), que regulava a possibilidade de terceirização de atividadesmeio, quanto a Lei n. 13.429/2017, que valida a terceirização inclusive de atividades-fim, pela qual se evidencia que a mudança legislativa confere mais vantagens à classe dos empresários, decorrentes da precarização das condições de trabalho da classe trabalhadora, esperamos apresentar pontos de resistência que permitam a manutenção das garantias trabalhistas, ainda que vigentes não só a lei de terceirização, mas a lei que desvalorizou as normas protetivas do trabalhador constantes da CLT, lei essa que tem sido chamada de lei da Reforma Trabalhista.

Por fim, após as ponderações feitas acerca dos dispositivos que tratam da terceirização, serão observadas suas implicações no contexto das relações laborais e, a partir disso, pretendemos concluir no sentido da total ineficácia da terceirização das atividades-fim, em virtude da inafastabilidade do sistema protetivo do Direito do Trabalho, algo que nem a Lei $\mathrm{n}$. 13.429/2017, nem a Reforma Trabalhista, têm legitimidade para alterar.

\section{O Direito do Trabalho e a relação de emprego}

O Direito do Trabalho é um ramo jurídico especializado, que orienta e regula determinado tipo de relação de labor na sociedade contemporânea. Pode-se dividir sua definição em dois aspectos: o subjetivo, que diz respeito aos sujeitos envolvidos na relação de trabalho, não só na relação de emprego 
(empregador e empregado), e o objetivo, que direciona o enfoque da matéria, seu conteúdo.

Reunindo ambos os aspectos mencionados, tem-se que o Direito do Trabalho é composto por normas, princípios e institutos aplicáveis à relação de trabalho, bem como às situações equiparáveis, que se preocupam com o trabalhador e com as relações laborais em que estão inseridos, por meio de medidas protetoras.

No âmbito do Direito do Trabalho, ainda se exige das partes a formalização precisa do contrato de trabalho e o cumprimento de todos os elementos contratuais, $1 \mathrm{sem}$ os quais o contrato deve ser considerado viciado e, portanto, nulo. Na relação de emprego, a prestação de serviço deve ser feita por um empregado, de modo habitual e sob subordinação ao empregador, que o remunera.

Em busca da otimização de lucros, os grandes empresários passaram a promover a contratação mercantil de tomadoras de serviço, para realizarem o trabalho antes realizado por empregados. Esta é a razão de ser da terceirização de mão de obra, formalizada juridicamente pelo negócio acertado entre dois empresários, um tomador, outro prestador do serviço. Em outras palavras, trata-se de um contrato civil ou comercial entre duas pessoas jurídicas, por meio do qual os empregados da prestadora exercem funções de interesse da tomadora, geralmente dentro do estabelecimento comercial desta última.

Pela terceirização, ocorre a transferência de parcelas da cadeia produtiva da tomadora para a prestadora de serviços, cuja vantagem, a redução dos custos de produção da tomadora, decorre da precarização do trabalho que está por trás desta contratação civil ou empresarial, principalmente porque os salários pagos aos seus trabalhadores da prestadora são menores que os pagos pela tomadora aos seus próprios empregados.

Por óbvio, mediante a ocorrência das modificações na organização do trabalho e, consequentemente, nas relações trabalhistas que ocorriam ao longo do tempo, estas deixaram de ser simplificadas, em decorrência da descentralização, para se tornarem complexas. A descentralização, por sua

\footnotetext{
${ }^{1}$ Todos os elementos são extraídos dos artigos 2ำ e 3ำ da Consolidação das Leis do Trabalho e são, em síntese, cinco: pessoa física do empregado; o vínculo de pessoalidade (relação "intuitu personae"); a nãoeventualidade; a subordinação e a onerosidade. A Justiça do Trabalho, porém, tem considerado que até mesmo prestações de serviço sem a adequada formalização se caracterizam como relações de emprego, visando à proteção do trabalhador.
} 
vez, é a divisibilidade técnica da cadeia de produção, ou seja, determinados empresários passam a transferir às pequenas pessoas jurídicas a produção de parte do processo produtivo.

Assim, com a crescente descentralização da produção, surge o fenômeno da terceirização do trabalho, que propicia o surgimento de uma nova gestão dos processos produtivos e que implica profundas transformações sociais e econômicas, que se materializam na necessidade dos empresários de flexibilizar as relações entre capital e trabalho, ao mesmo tempo em que ampliam seus aparatos de manutenção do modo de produção capitalista (OLIVEIRA, 2013, p. 190), como será analisado a seguir.

\subsection{A Reforma Trabalhista trazida pela Lei $n .13 .467$ de 13 de julho de 2017: fortalecimento da relativização das normas protetivas do trabalhador}

A Lei n. 13.467, de 13 de julho de 2017, conhecida como Lei da Reforma Trabalhista, trouxe alteração em diversos pontos da Consolidação das Leis do Trabalho.

Na verdade, a Reforma Trabalhista teve por escopo eliminar o sentido da existência da Justiça do Trabalho: a CLT foi criada para conferir proteção ao polo mais vulnerável da relação trabalhista, e a Reforma veio para tratar as partes como se estas estivessem em igualdade de condições. $O$ conceito de autonomia da vontade entre as partes da relação laboral foi ampliado, relativizando-se e até revogando-se princípios protecionistas e, até aqui, norteadores das relações de trabalho, tais como os da irrenunciabilidade e da indisponibilidade de direitos.

O legislador da Reforma limitou a atuação do Poder Judiciário no tocante à análise das negociações coletivas, que compreendem os acordos coletivos de trabalho e as convenções coletivas de trabalho, 2 conferindoIhes a possibilidade de se sobreporem à lei quando dispuseram sobre determinados temas. As normas coletivas de trabalho não mais poderiam ser contestadas judicialmente, conforme a nova redação dada pela Reforma aos artigos 8으, §3으, e 611-A, §1으, da CLT.

\footnotetext{
${ }^{2}$ Norma coletiva de trabalho tem por objeto a melhoria das condições de trabalho que, uma vez estabelecidas, não poderão ser suprimidas. Pode ser pactuada entre o sindicato representativo da categoria profissional e os empregadores (Acordo Coletivo), ou entre aquele e o sindicato representativo da categoria econômica-empregadores (Convenção Coletiva).

3 Art. 8‥ As autoridades administrativas e a Justiça do Trabalho, na falta de disposições legais ou contratuais, decidirão, conforme o caso, pela jurisprudência, por analogia, por equidade e outros
} 
O maior poder concedido às negociações coletivas atrelado à expansão da autonomia da vontade das partes é responsável pela acentuação do processo de precarização do trabalho, pois passa a assentir a inobservância das normas trabalhistas, dado que, por força da Reforma Trabalhista, o "negociado poderá prevalecer sobre o legislado" e propor fim a direito sem sequer os revogar. Esta nova realidade favorece, assim, a regressão dos direitos sociais, possibilitando, inclusive, que às negociações coletivas possam se sobrepor as negociações individuais, prejudicando-as.

Se, por um lado, se verifica a extensão dos poderes de negociação no que tange às normas coletivas, por outro, é inegável que as alterações abarcadas pela Reforma Trabalhista também afetam potencialmente a atuação das entidades sindicais, em face da retirada da obrigatoriedade da contribuição sindical, exigindo, agora, expressa e prévia autorização do trabalhador para pagamento desse valor4 aos sindicatos.

Evidente que todo este cenário também repercute na terceirização e a Reforma Trabalhista, na tentativa de mascarar a precarização, a rotatividade e a informalidade do trabalho, estipulou, na nova redação da CLT, em seu artigo 5--D,5 um período de "quarentena", que consiste na impossibilidade de o empregado que teve seu contrato de trabalho rescindido prestar serviços para a mesma empresa, na qualidade de empregado de empresa prestadora de serviços, antes do decurso de prazo de 18 (dezoito) meses, contados a partir da demissão do empregado.

Não obstante a relevância do impedimento da recontratação do empregado como terceirizado, a problemática que envolve o enquadramento sindical do terceirizado, que há tempos vem sendo

\footnotetext{
princípios e normas gerais de direito, principalmente do direito do trabalho, e, ainda, de acordo com os usos e costumes, o direito comparado, mas sempre de maneira que nenhum interesse de classe ou particular prevaleça sobre o interesse público.

§ 3 № exame de convenção coletiva ou acordo coletivo de trabalho, a Justiça do Trabalho analisará exclusivamente a conformidade dos elementos essenciais do negócio jurídico, respeitado o disposto no art. 104 da Lei n. 10.406, de 10 de janeiro de 2002 (Código Civil), e balizará sua atuação pelo princípio da intervenção mínima na autonomia da vontade coletiva."

"Art. 611-A. A convenção coletiva e o acordo coletivo de trabalho têm prevalência sobre a lei quando, entre outros, dispuserem sobre:

$\S 1$ 을 No exame da convenção coletiva ou do acordo coletivo de trabalho, a Justiça do Trabalho observará o disposto no § 3어 do art. 8어 desta Consolidação.

${ }^{4}$ Art. 545. Os empregadores ficam obrigados a descontar da folha de pagamento dos seus empregados, desde que por eles devidamente autorizados, as contribuições devidas ao sindicato, quando por este notificados.

${ }^{5}$ Art. 5o-D 0 empregado que for demitido não poderá prestar serviços para esta mesma empresa na qualidade de empregado de empresa prestadora de serviços antes do decurso de prazo de dezoito meses, contados a partir da demissão do empregado.
} 
debatida, não foi enfrentada pela Reforma, tampouco pela Lei $\mathrm{n}$. $13.429 / 2017$.

Sem dúvidas, as inovações trazidas pela Reforma Trabalhista foram responsáveis por um significativo retrocesso, do ponto de vista social; porém, sob a ótica econômica, se manifestam como um grande passo para os empregadores, na medida em que permitem que a parte mais frágil da relação de trabalho --o trabalhador-- perca direitos já conquistados, numa imensa precarização de suas condições de trabalho. Porém, a unicidade sindical de todos os trabalhadores que exercem funções na atividade-fim, sejam eles contratados diretamente pela tomadora de serviços, sejam eles terceirizados, permite resistir à precarização por meio de negociações coletivas assumidas pelo único sindicato da categoria. Claro que essa resistência pressupõe sindicatos fortes e bem organizados e não farsas sindicais travestidas de sindicatos de trabalhadores.

\subsection{O fenômeno da terceirização nos contratos de trabalho}

No final do século $X X$ e início do século $X X I$, acentuou-se a radicalização dos processos de concentração de riquezas, que culminou na aparição dos oligopólios, na multiplicação das incorporações empresariais e das fusões, ao mesmo tempo em que cresciam em número as micro, pequenas e médias empresas, formando as cadeias de subcontratação e terceirização. Isto posto, estas transformações no modo de gestão e na sistematização do trabalho foram definitivas para criar o pano de fundo em que se insere a terceirização.

Essa realidade é descrita pelas pesquisadoras Graça Druck e Tânia Franco (2008, p. 83-84), no campo histórico, como um novo padrão de desenvolvimento no capitalismo. No âmbito das novas práticas de organização e gestão do trabalho, a terceirização se apresenta, para elas, como o principal exemplo inserido neste quadro de mundialização produtiva e de implementação de políticas neoliberais de flexibilização da relação de trabalho.

A terceirização, entendida como forma de organização de produção capitalista, não se mostra como um fenômeno novo, posto que desde o século XVIII ela já era observada. Isso porque os primeiros passos do capitalismo industrial foram marcados pelo esforço contínuo do capitalista para comprar força de trabalho da mesma maneira que obtinha as matérias- 
primas necessárias para produção, qual seja como "uma determinada quantidade de trabalho, completa e incorporada no produto", como bem observa Batista (2010, p. 62).

No século XIX, é possível constatar a origem da terceirização no Brasil, em especial na indústria têxtil, na produção de sacas (BATISTA, 2010, p. 63). Certamente, este instituto propiciou o (re)aparecimento de algumas formas de trabalho precário, mas que agora impõe a exploração que ocorre de todo modo, mesmo nas relações formais, seja no âmbito da prestação de serviços ou na circulação de mercadorias.

Mais precisamente a partir da década de 50 do século $X X$, foi que a terceirização como modo de gestão organizacional sobreveio, em especial com a instalação das indústrias automobilísticas, que acabaram por externalizar algumas parcelas de sua produção, constituindo ao seu redor indústrias satélites ou empresas de autopeças, que forneciam os componentes e os serviços necessários para a montagem do produto final pelas transnacionais. No entanto, foi somente na década de 1980 que este processo se consolidou, na medida em que se constituiu um emaranhado de "empresas especialistas ou subcontratadas para desempenhar tarefas e serviços que, anteriormente, eram realizados no próprio interior das empresas" (MATTOSO, 1999, p.26).

Desta feita, a terceirização, sob a óptica de Giovanni Alves (1999, p. 152), é uma espécie de descentralização produtiva, centrada na lógica da "focalização" da produção, permitindo que o empresário concentre seus esforços e que se especialize na produção de mercadorias sobre as quais detém evidentes vantagens competitivas.

Este novo modelo de reorganização da cadeia produtiva, que se caracteriza pela minimização de custos, maximização de resultados econômicos, precarização do trabalho e dos direitos trabalhistas, que refletem no movimento sindical, impõe que até mesmo os trabalhadores com maior grau de escolaridade se tornem seus reféns, considerando que podem laborar em setores que correspondem apenas a parte do processo produtivo, que requer mão de obra menos qualificada.

O deslocamento dos encargos trabalhistas e da responsabilidade de gerir dos empresários para pessoas jurídicas prestadoras de serviços, as quais fornecerão seus empregados como mão de obra, torna-se o principal ponto atrativo da terceirização, considerando que proporciona uma redução de custos para o empresário tomador de serviços. 
Ora, a relação empresário-trabalhador é regida pelo Direito do Trabalho. Porém, com a terceirização, o dono dos meios de produção (empresário) e principal interessado na realização dos serviços que comporão sua linha de produção, agora tomador de serviços, se exime das normas estipuladas pelo Direito do Trabalho, passando a conduzir seus negócios por meio da contratação comercial de outras pessoas jurídicas, ora prestadoras de serviços que, por seu turno, utilizam seus trabalhadores para servir de mão de obra para o empresário, e são por eles responsáveis.

Enquanto a mão de obra terceirizada for utilizada sem o respeito às normas protetivas do trabalho, ela continuará sendo mera técnica para burlar normas trabalhistas. Ademais, a terceirização, que ganhou espaço num momento em que se viu a necessidade de "racionalizar recursos, redefinir suas operações, funcionar com estruturas mais enxutas e flexíveis, funcionando como um instrumento de auxílio à necessária reestruturação organizacional ao incremento da produtividade e competitividade" (COSTA, 1994, p. 7), não deveria ser usada em quaisquer atividades.

\subsection{As distinções entre atividade-meio e atividade-fim}

É certo que o ramo empresarial também busca obter a excelência em suas atividades, reunindo seus esforços no aperfeiçoamento e desenvolvimento do seu produto final. Todavia, o objeto primordial de qualquer empresário é a conquista do lucro, mediante a venda de produtos ou a prestação de serviços, que é sua atividade-fim. Para otimizar suas atividades e maximizar o retorno de investimentos, não é incomum a desativação total ou parcial de parques industriais, dado o custo de sua manutenção, com a delegação das atividades ali desenvolvidas para outros empresários com custos menores de produção (COSTA, 1994, p. 3).

O lucro decorrente da venda do produto final pertence ao empresário tomador. As pessoas jurídicas terceirizadas também se remuneram mas, para que a lógica da terceirização funcione, este valor tem de ser menor que o custo que a tomadora teria se contratasse diretamente empregados para a realização da atividade terceirizada. Não há nenhuma dúvida, portanto, de que essa prática privilegia apenas o setor empresarial, ao passo que lesa a principiologia protetiva do Direito do Trabalho, afrontando diretamente sua finalidade, em que pese a Súmula 331 do TST já ter legitimado a terceirização 
das atividades-meio, antes de sobrevir a consagração da terceirização nas atividades-fim pela Lei $n$. 13.429/2017.

Importa, nesse sentido, conhecer a distinção entre a atividade-fim e a atividade-meio segundo o posicionamento atual do Tribunal Superior do Trabalho. A primeira é aquela principal, essencial, que é inerente ao objeto social do empresário, ora tomador de serviços. Por outro lado, a atividademeio é aquela acessória, de apoio, que não se confunde com o núcleo da dinâmica empresarial do mesmo tomador, apesar de também ser necessária para o funcionamento do processo de produção.

Conforme entendimento até então predominante, por força da Súmula 331 do TST, era permitida a utilização de empregados terceirizados apenas nos serviços compreendidos como atividade-meio do empresário terceirizante. Porém, na prática, a distinção não era tão simples, eis que o Poder Judiciário, muitas vezes, de acordo com cada caso concreto, não consegue definir os limites entre a atividade-fim e atividade-meio.

$\mathrm{Na}$ busca de solucionar o embaraço quanto à fixação da divisa entre atividade-meio e atividade-fim, deve-se verificar, pelo objeto social do empresário, a finalidade para qual a pessoa jurídica fora constituída, isto é, qual é o seu ramo de atuação. A atividade que consta como objeto social do estatuto ou contrato da sociedade empresária é sua atividade-fim, relacionada ao resultado final da cadeia produtiva. 6

Embora o Direito do Trabalho vise à proteção do trabalhador e à garantia das condições de trabalho, a estrutura normativa não foi capaz de impedir a terceirização de atividades-meio, e até acabou por se legitimar a terceirização das atividades-meio pela edição da Súmula 331, algo que já se agravou com a aprovação da Lei n. 13.429 de 2017.

\section{A precarização do trabalho: aumento da produtividade versus redução de custos}

\footnotetext{
${ }^{6}$ Sendo assim, as demais são enquadradas como atividades-meio, cuja terceirização é legitimada exclusivamente por não se relacionar à finalidade da atividade empresarial, como se o produto pudesse ser produzido sem tais meios (como se o fim pudesse ser atingido sem tais atividades-meio). Não obstante, a partir deste exame do objeto social, ainda se encontram obstáculos para identificar o alcance da terceirização com relação à diversidade de atividades. Trata-se, desta forma, de algo difícil de especificar dentro da dinâmica do processo produtivo, o que é e o que não é a essência nuclear do empresário. Portanto, não é tão fácil apontar a licitude ou ilicitude da terceirização, em face da subjetividade da distinção entre atividade-meio e atividade-fim.
} 
É certo que as revoluções industriais contribuíram muito para que a precarização do trabalho fosse ampliada em todo o mundo, a partir das mudanças, já mencionadas no item anterior, na organização do processo produtivo. Na verdade, o processo de reestruturação produtiva excede as novas formas de organização do trabalho, sendo responsável pela reordenação das forças produtivas e dos padrões de concorrência (KREMER, FARIA, 2005, p. 267).

Dentre as alterações estruturais no modo de organizar o trabalho, é notável o crescimento da implementação do processo de terceirização nos mais diversos ramos produtivos, que passa a ter influência na lógica de dominação capitalista, bem como traz novos impactos nos âmbitos social e econômico.

Assim, em síntese, sob a ótica de Pinheiro-Machado (2008, p. 118), em face da realidade vigente, em que a pobreza, o desemprego e o trabalho precário são efetivos em países em desenvolvimento, concebe-se a ideia de não pensar que os trabalhos informais ou flexíveis são como uma "bolha", que flutua à margem do mercado capitalista, mas, como parte inerente desse mercado e que está fixada ao sistema econômico. A terceirização, para os seus defensores, é um desdobramento natural da segmentação do trabalho no capitalismo e da globalização. Segundo esta visão, ela não funciona apenas como instrumento de otimização do processo produtivo, mas também impulsiona o surgimento de novas pessoas jurídicas e até mesmo é capaz de expandir o número de postos de trabalho. Claramente, tais alegações são questionáveis, considerando que a terceirização, ao contrário, favorece a rotatividade de trabalhadores e piora os níveis de desemprego, como é demonstrado a seguir.

Com a sua rápida e ampla difusão, a terceirização, além dos trabalhadores terceirizados, também afeta os trabalhadores não terceirizados, haja vista que o empresário opta pela delegação de determinados serviços, secundários em relação à sua atividade principal, à pessoa jurídica que já tem seus próprios empregados para realizar as atividades delegadas.

O empresário tomador de serviços, então, dispensa os trabalhadores anteriormente contratados, face à vantagem de se celebrar contrato com pessoa jurídica prestadora de serviços, visto que, pelo contrato civil ou comercial, será obtida mão de obra mais barata que pela contratação direta de empregados, já que, na terceirizada, os empregados são contratados com 
salários inferiores ao salário-base da categoria profissional da atividade-fim, e na maioria das vezes sem organização sindical (ou com sindicato, porém sem qualquer capacidade efetiva de negociação para melhoria de condições da categoria).

Ricardo Antunes (2011, p. 3) observa bem esta conduta dos empresários na busca pela redução de custos e avalia a terceirização como algo destrutivo, já que precariza parcela significativa da força mundial de trabalho, pois desemprega cada vez mais trabalho estável, substituindo-o por trabalhos informais ou menos remunerados.

O aperfeiçoamento da tecnologia teve papel fundamental na construção deste novo paradigma no mundo de trabalho, não só por ter elevado a taxa de desemprego, posto que reduziu o número de operários necessários para a fabricação dos produtos, acabando com as habilidades manuais, mas também, de outra forma, por ter alavancado as formas precárias de trabalho, à medida que aqueles que trabalham são submetidos a longas jornadas, sem a observâncias de seus direitos, e, como contraprestação, recebem salários insuficientes para custear suas necessidades básicas e as de seus dependentes.

A reestruturação do trabalho modificou todo o conjunto da base produtiva, e foi responsável pelo encadeamento da precarização do trabalho. Aliás, a tendência de precarização das condições de trabalho a partir do advento das terceirizações é evidenciada pela perda salarial e de direitos, bem como o aumento da intensidade de trabalho e de riscos à saúde do trabalhador e das dificuldades experimentadas pelo sindicato em unificar as lutas comuns. Nesse sentido, a terceirização se opõe à noção de qualidade, precarizando as condições de trabalho e de emprego, além de prejudicar a qualidade da produção (DRUCK, 1995, p. 145).

Isto posto, em vez de se usar a prática de subcontratações a favor do desenvolvimento social e econômico, culminando na disseminação de pessoas jurídicas especializadas, pautadas na qualidade e na melhoria do processo produtivo, os empresários têm o apoio que precisam para, de forma elisiva, usar as normas trabalhistas em seu favor, por exemplo, pela terceirização de toda a estrutura relativa à produção de suas atividadesmeio, realçando a precarização do trabalho.

Neste aspecto, percebe-se que o próprio Direito do Trabalho, que foi criado para tutelar as relações de trabalho, é corrompido, pois os capitais globais exigem o desmonte da legislação social protetora do trabalho. E a 
redução dessa legislação de proteção social significa aumentar ainda mais os mecanismos de extração do sobretrabalho, ampliar as formas de precarização e destruição dos direitos sociais que foram arduamente conquistados (ANTUNES, 2011, p. 6).

O processo de terceirização, antes de ser uma estratégia de gerenciamento dos setores relativos à cadeia de produção, é uma tática de poder, que se preocupa muito mais com a dinâmica do capital financeiro, tendo em vista que o lucro provém da redução dos custos com o fator de produção, que é a mão de obra, o trabalhador em si. Assim, a precarização atinge, em primeiro plano, os trabalhadores terceirizados, dado que o aludido processo não fragmenta somente o trabalho, mas também a classe que trabalha (VIANA, 2009, p. 148).

Como consequência deste panorama, a classe trabalhadora terceirizada é obrigada a se sujeitar ao recebimento de um salário ínfimo ou, ao menos, menor que o salário da classe de trabalhadores que atuam na pessoa jurídica (empresa) tomadora do serviço subcontratado, bem como à redução de outros direitos trabalhistas, ou, até mesmo à sua ausência, em troca de seu sustento e de sua respectiva família, favorecendo os interesses dos donos dos meios de produção.

Aliás, a qualidade dos postos de trabalho também vem sendo deteriorada, considerando o descumprimento de normas de segurança, de meio ambiente e de medicina do trabalho, em face do aumento do número de doenças e acidentes oriundos da atividade laboral e da realização de jornadas de trabalho extenuantes, situação que pode ser agravada pelas novas diretrizes trazidas pela Reforma Trabalhista, uma vez que propaga uma pretensa liberdade maior de contratação entre os sujeitos da relação de trabalho.

A problemática que envolve a terceirização está exatamente no dever de assistir o trabalhador e tutelar suas relações, que é a função típica do Direito do Trabalho, pois a legislação trabalhista não conseguiu intervir e se adequar de maneira satisfatória à velocidade com que este fenômeno se infiltrou no processo produtivo, deixando o ordenamento jurídico, neste tocante, repleto de lacunas ou/e soluções imediatistas, também conhecidas como "tapa-buracos".

\section{Normatização da Terceirização: Súmula 331 do Tribunal Superior do Trabalho e Lei n. 13.429/2017}


A Consolidação das Leis do Trabalho (CLT) não regulava especificamente o instituto da terceirização. Com a Reforma Trabalhista, esse ponto se manteve sem regulamentação. A Súmula 331 do TST, editada antes da aprovação da Lei n. 13.429/2017 enunciava as condições para se considerar uma terceirização lícita ou ilícita.

O texto da Súmula, da forma como foi elaborado, já proporcionava a abertura deum leque de oportunidades para a expansão e utilização da terceirização da forma que ela for mais conveniente aos empresários, o que foi aclamado pela Lei n. 13.429 que, aliás, expandiu as hipóteses de admissão, incluindo as atividades-fim.

Os Tribunais do Trabalho já vinham reconhecendo que o empresário possuía a liberdade para promover quaisquer terceirizações, desde que não as fizesse nas atividades-fim de sua empresa; ao reconhecer tal situação, porém, permite que o trabalho necessário à produção perca proteção e se precarize. Afinal, só há terceirização em situações em que haja redução de custos, e a redução de custos, em regra, ocorre por meio de cortes na folha de pagamento.

No aspecto social, tanto a Súmula quanto a Lei n. 13.429 deixam de atentar ao que é primordial, que é a proteção ao trabalhador, pois permitem a redução da estrutura de proteção do trabalho em relação aos trabalhadores terceirizados. Em outras palavras: quem é terceirizado tem ainda menos direitos.

A perspectiva do TST, ao criar a Súmula 331, foi a de garantir o empreendimento empresarial, e não a da manutenção dos direitos do trabalhador, valendo-se da lacuna legislativa, antes do advento da Lei $\mathrm{n}$. 13.429. Isto permitiu a transformação da terceirização, que teoricamente se apresentava como técnica de eficiência da produção, em método que, na prática, manifestamente precariza as condições do trabalho (MAIOR, 2004, p. 2).

Desta feita, é muito mais proveitoso para o empresário contratar uma pessoa jurídica prestadora de serviços, que remunera trabalhadores com salários muito mais baixos em relação àqueles que recebem seus empregados, eis que estes são contratados pelo salário-base de sua categoria profissional na atividade-fim. Não existe, portanto, tratamento igualitário entre os trabalhadores terceirizados e os não-terceirizados. 
O Direito do Trabalho teria a função de promover a humanização das relações de trabalho que são, por definição, relações de desigualdade entre as partes envolvidas. Assim, a permissão da terceirização vai de encontro ao fundamento das normas trabalhistas, sobretudo as constitucionais, reforçando a disparidade entre as partes e afastando a isonomia de direitos e benefícios dos trabalhadores da pessoa jurídica principal, a tomadora, e daqueles da pessoa jurídica subcontratada, a prestadora de serviços.

A tomadora de serviços só será responsabilizada de forma subsidiária, nos termos que dispõem os itens IV e VI da Súmula 331 do TST,7 bem como o artigo 5--A, §5 da CLT,8 com redação dada pela Lei n. 13.429 de 2017, se e quando as práticas irregulares quanto à terceirização chegarem ao conhecimento do Poder Judiciário. Muitos trabalhadores acabam por não ajuizar reclamações trabalhistas, seja por desconhecimento ou até mesmo por medo de represália ou de não conseguirem novo emprego.

Aliás, ainda que tomadora de serviços venha, porventura, a ter sua responsabilidade reconhecida em juízo, o valor a ser pago a título de indenização será calculado sobre o salário que era recebido pelo terceirizado, e não sobre o salário que o terceirizado teria se fosse diretamente contratado pela tomadora. Isto mostra a terceirização orientada antes pela Súmula 331 e agora pela Lei n. 13.429/2017 é iníqua, visto que promovem a desvalorização do trabalho e afrontam os princípios constitucionais que regem o Direito do Trabalho.

Há, ainda, outro ponto importante a ser mencionado como efeito da terceirização. Os terceirizados não possuem representação sindical da categoria profissional dos empregados da tomadora de serviços e, embora tenha ocorrido a reestruturação das normas relativas ao Direito do Trabalho e Processo do Trabalho pela Reforma Trabalhista, não houve nesta qualquer menção quanto às novidades trazidas pela Lei $n$. 13.429 sobre terceirização e enquadramento sindical dos terceirizados.

\footnotetext{
${ }^{7}$ Súmula 331, item IV, TST: “O inadimplemento das obrigações trabalhistas, por parte do empregador, implica a responsabilidade subsidiária do tomador dos serviços quanto àquelas obrigações, desde que haja participado da relação processual e conste também do título executivo judicial."

Súmula 331, item VI, TST: "A responsabilidade subsidiária do tomador de serviços abrange todas as verbas decorrentes da condenação referentes ao período da prestação laboral."

${ }^{8}$ Art. ${ }^{5}$--A. Contratante é a pessoa física ou jurídica que celebra contrato com empresa de prestação de serviços determinados e específicos.

§ 5ㅇ A empresa contratante é subsidiariamente responsável pelas obrigações trabalhistas referentes ao período em que ocorrer a prestação de serviços, e o recolhimento das contribuições previdenciárias observará o disposto no art. 31 da Lei n. 8.212, de 24 de julho de 1991.
} 
A Lei n. 13.429, na tentativa de justificar a mínima observância às normas trabalhistas, estipula, em seu artigo 50-A, §3의 a responsabilidade do empresário pelas condições de segurança, higiene e salubridade dos trabalhadores terceirizados, caso as atividades sejam desempenhadas em suas dependências ou local anteriormente estabelecido em contrato, permitindo, ainda, que a tomadora dos serviços forneça a mesmas condições de alimentação no refeitório da empresa em que trabalham, serviços de transporte, ambulatórios e sanitários, não havendo, porém, qualquer pronunciamento quanto à remuneração e enquadramento sindical do terceirizado, que é a questão mais importante a ser aqui discutida, inclusive no âmbito da Reforma Trabalhista.

Sem menção ao dever de unicidade sindical, os terceirizados que atuam na atividade-fim da empresa tomadora de serviços recebem salários inferiores ao piso daquela categoria e possuem menos garantias que os trabalhadores subordinados diretamente à tomadora de serviços (os nãoterceirizados).

Mesmo os sindicatos mais fortes, na busca pela proteção e garantia do cumprimento dos direitos trabalhistas, encontram sérias dificuldades em pactuar a normatização dos usos que os empresários fazem da terceirização. Ora, para as normas coletivas serem benéficas ao terceirizado, os sindicatos, funcionando como instrumento de união e fortalecimento da categoria, precisariam ser fortes e independentes.

Se a categoria é pouco organizada e os sindicatos são dependentes da categoria econômica, as normas coletivas não serão hábeis sequer para garantir direitos já existentes; aliás, nem possuem força para conquistarem ou manterem direitos trabalhistas a partir de negociação coletiva.

Aliás, como já ressaltado no início desse artigo, a Reforma Trabalhista propicia o sucateamento das normas trabalhistas, porquanto atribui amplos poderes às negociações coletivas e reconhece a autonomia ampliativa da vontade nos contratos de trabalho.

Esta realidade perversa, já legitimada pelo TST pela Súmula 331 e, agora, também pela Lei n. 13.429, que ampliou as hipóteses de cabimento da terceirização, traz muitas preocupações com relação ao futuro da mão de obra terceirizada, pois a terceirização indiscriminada não deveria significar um obstáculo ao respeito integral dos direitos trabalhistas.

\footnotetext{
${ }^{9}$ §3 É responsabilidade da contratante garantir as condições de segurança, higiene e salubridade dos trabalhadores, quando o trabalho for realizado em suas dependências ou local previamente convencionado em contrato.
} 


\section{As principais inovações da Lei n. 13.429/2017}

O entendimento, segundo a Súmula 331 do TST é no sentido de que não há a formação de vínculo de emprego entre trabalhador e tomadora, sempre que a terceirização se der em atividade-meio. Por outro lado, havendo terceirização de atividade-fim, ou seja, até então, supostamente, ilícita, impõe-se o reconhecimento da relação de emprego entre as partes.

Todavia, contrariando a posição assumida pelo Tribunal Superior do Trabalho, a Lei n. 13.429/2017, em seu artigo 40-A, § 2o,10 propõe a nãocaracterização de vínculo empregatício entre o trabalhador e a tomadora de serviços, mesmo em caso de transferência de atividade-fim a terceiros.

A ideia é que, com a vigência dessa lei, os trabalhadores terceirizados atuem na atividade-fim da tomadora de serviços, sem que se reconheça a relação de emprego entre terceirizado e tomador de serviços, retirando dos trabalhadores a possibilidade de lhes ser conferida a mesma proteção e os mesmos direitos concedidos aos trabalhadores não-terceirizados.

Nesse sentido, as principais inquietações trazidas pela Lei $\mathrm{n}$. 13.429/2017 se referem à expansão das possibilidades de terceirização de mão de obra, algo que está explícito nas disposições dessa lei, e ao enquadramento sindical do terceirizado quando contratado para o desempenho de atividade-fim, e a respeito disso são silentes tanto a Lei da Terceirização quanto a Lei da Reforma Trabalhista.

A Lei da Terceirização - Lei n. 13.429/2017- permite agora que não só as atividades-meio sejam objeto de terceirização, mas quaisquer atividades, compreendendo, também, as atividades-fim, que passariam a integrar o rol daquelas passíveis de serem delegadas. Esta, sem dúvidas, é a maior inovação pela legislação em comento, já que que a prática de terceirização de atividades-fim, era, até antes de sua vigência, vedada até mesmo pela Súmula 331 do TST.

A diversidade de atividades passíveis de terceirização pode ser uma preocupação ainda maior, no que tange à atuação dos sindicatos dos empregados, principalmente, quanto ao enquadramento sindical do

\footnotetext{
${ }^{10}$ Art. 40-A. Empresa prestadora de serviços a terceiros é a pessoa jurídica de direito privado destinada a prestar à contratante serviços determinados e específicos.

$\S 2$ ㅇ Não se configura vínculo empregatício entre os trabalhadores, ou sócios das empresas prestadoras de serviços, qualquer que seja o seu ramo, e a empresa contratante.
} 
trabalhador terceirizado que desempenha suas funções na atividade-fim da tomadora de serviços. Afinal, a qual categoria de trabalhadores ele pertenceria?

\section{A questão da representação e atuação sindicais do terceirizado na atividade-fim}

Frente à intensidade das transformações sociais e econômicas que ocorreram na reorganização do trabalho e que levaram à relativização das normas protetivas do trabalhador, a classe trabalhadora se viu na necessidade de reunir esforços para lutar contra a dominação do capital e reprimir os abusos decorrentes da superexploração da mão de obra por parte dos donos dos meios de produção.

Assim, os trabalhadores se movimentavam e se agrupavam, a fim de reivindicar seu reconhecimento como elemento importante na produção, o que só seria possível por meio de pagamento de salário mais digno, capaz de custear seu sustento e de seus familiares, e melhores condições laborais, como a segurança do trabalho e a redução de jornada.

No Brasil, a Constituição Federal, em seu artigo 8o, II,11 assegura aos trabalhadores o livre exercício de organização sindical representativa de categoria profissional, localizada em determinada base territorial, não podendo ser inferior à área de um Município.

Logo, o sindicato de empregados, que é formado pela união de membros de determinada profissão, visa à defesa e à representação da referida profissão, na busca pelo aprimoramento das condições de trabalho. A CLT, em seu artigo 511,12 também reconhece a licitude da organização sindical e, partir de sua leitura, pode-se compreender a categoria profissional como um conjunto de trabalhadores que, continuamente, têm identidade de interesses em virtude da atividade que desempenha.

\footnotetext{
${ }^{11}$ Art. 8ㅇ, CF: “É livre a associação profissional ou sindical, observado o seguinte: II - é vedada a criação de mais de uma organização sindical, em qualquer grau, representativa de categoria profissional ou econômica, na mesma base territorial, que será definida pelos trabalhadores ou empregadores interessados, não podendo ser inferior à área de um Município;"

12 Art. 511, CLT: "É lícita a associação para fins de estudo, defesa e coordenação dos seus interesses econômicos ou profissionais de todos os que, como empregadores, empregados, agentes ou trabalhadores autônomos ou profissionais liberais exerçam, respectivamente, a mesma atividade ou profissão ou atividades ou profissões similares ou conexas."
} 
A representação sindical é genérica, ou seja, quando há ajuste de norma coletiva de trabalho, conforme resguarda o artigo 611 , §1ํㅡ, da CLT,13 sua eficácia atinge o conjunto de indivíduos que compõem a categoria, mesmo que os trabalhadores não sejam filiados ao sindicato.

Quanto à categoria profissional, seu enquadramento sindical se dá, como regra, pela similitude laborativa, ou seja, pela vinculação a empregadores que exerçam atividades econômicas idênticas, similares ou conexas, nos termos §2o 14 do artigo 511 da CLT. Em suma, o enquadramento sindical do empregado será determinado pela atividade preponderante desenvolvida pelo empresário que qualifica seus empregados, que é a sua atividade-fim, como assinala o §2으 do artigo 581 da CLT.15

Não faz sentido, portanto, imaginar-se a existência de dois sindicatos a representar uma mesma categoria, um a representar os trabalhadores contratados diretamente pelo empresário, e outro a representar os trabalhadores terceirizados que realizariam os mesmos serviços na mesma atividade-fim daquele mesmo empresário. De igual modo, também se mostra incoerente a constituição de um sindicato de trabalhadores terceirizados, que desempenham suas atividades para diversas tomadoras de serviços que, por sua vez, pertencem a diferentes setores econômicos, visto que confronta com as ideias de unidade e associação de indivíduos com interesses comuns, que perfazem a essência do sindicato.

A questão da representação sindical se torna importante na hipótese de o empregado terceirizado exercer a atividade-fim da tomadora de serviços, nos termos que preconiza a Lei n. 13.429/2017. A unidade sindical impõe ao sindicato da categoria representar todos os trabalhadores na atividade-fim dos empresários, o que, sem dúvida, deve incluir os terceirizados, não havendo que se falar em divisão de representação entre

\footnotetext{
${ }^{13}$ Art. 611, CLT: “Convenção Coletiva de Trabalho é o acôrdo de caráter normativo, pelo qual dois ou mais Sindicatos representativos de categorias econômicas e profissionais estipulam condições de trabalho aplicáveis, no âmbito das respectivas representações, às relações individuais de trabalho. §1ㅇ́ facultado aos Sindicatos representativos de categorias profissionais celebrar Acordos Coletivos com uma ou mais emprêsas da correspondente categoria econômica, que estipulem condições de trabalho, aplicáveis no âmbito da emprêsa ou das acordantes respectivas relações de trabalho."

${ }^{14}$ Art. 511, § 2ㅇ, CLT: "A similitude de condições de vida oriunda da profissão ou trabalho em comum, em situação de emprego na mesma atividade econômica ou em atividades econômicas similares ou conexas, compõe a expressão social elementar compreendida como categoria profissional."

${ }^{15}$ Art. 581, § 20, CLT "Entende-se por atividade preponderante a que caracterizar a unidade de produto, operação ou objetivo final, para cuja obtenção todas as demais atividades convirjam, exclusivamente em regime de conexão funcional."
} 
os sindicatos dos não-terceirizados e um eventual sindicato dos terceirizados.

Cabe, portanto, ao sindicato da categoria, e a nenhum outro, salvaguardar os direitos trabalhistas, inclusive dos trabalhadores terceirizados. Nesse sentido, não nos parece que a nova legislação relativa à terceirização teria qualquer utilidade para os empresários: ela não terá qualquer eficácia no sentido de autorizar contratação de empregados terceirizados, no exercício de atividades-fim, com valor de remuneração inferior ao piso da categoria já conquistado por seu respectivo sindicato profissional.

A propósito, ainda que todos os empregados diretos sejam dispensados e substituídos por trabalhadores terceirizados, prática que a Reforma Trabalhista não veda, mas estipula um período de quarentena para recontratação do empregado como terceirizado, a entidade sindical deverá declarar sua legitimidade para representá-los, e deverá batalhar pela permanência e ampliação dos direitos protetivos já alcançados, pois deve ser considerado ilícito, segundo o sistema de proteção do Direito do Trabalho ainda em vigor, a despeito da Reforma Trabalhista, que os trabalhadores no exercício das atividades-fim do empresário recebam valor inferior ao piso da categoria.

\section{0 sindicato poderá negociar a redução de direitos: mas isso só é válido para trabalhadores associados e não para toda a categoria}

Como regra, os sindicatos da categoria podem e devem negociar com o empresário ou sindicato patronal, no sentido de expandir direitos trabalhistas, aplicando-os não apenas a seus associados, mas também a todos os trabalhadores pertencentes àquela categoria.

A partir da vigência da nova redação da CLT, oriunda da Reforma Trabalhista, as negociações coletivas passam a ter mais força normativa, quando comparadas à legislação vigente até a entrada em vigor da Reforma, já que, nos termos desta, deve prevalecer o que é acordado nas negociações sobre o que está estabelecido em lei.

Até antes da Reforma Trabalhista, os acordos não tinham como reduzir direitos (ou retirar sua aplicação) garantidos por lei, e toda negociação permitia que as conquistas se estendessem a todos os trabalhadores da categoria representada pelo sindicato profissional. 
Com a Reforma, está dito que o sindicato teria capacidade para negociar supressão de direitos previstos na legislação, ou substituir direitos legais por vantagens obtidas por negociação. Porém, na hipótese em que a negociação coletiva suprima direitos legais, como aceitar que essa supressão atinja além dos trabalhadores sindicalizados? Parece-nos evidente que o sindicato só tem poderes para negociar redução de direitos em favor de trabalhadores associados e não em favor de toda uma categoria. Afinal, autorizar uma associação a reduzir direitos da pessoa é algo que só pode ocorrer mediante expressa vontade da pessoa ou mediante expressa determinação legal. O que não é o caso da negociação coletiva que consta da Reforma Trabalhista.

\section{A negociação coletiva pela qual direitos são suprimidos só será válida se impuser, em troca, que direitos com valor equivalente sejam conquistados}

De todo modo, mesmo em uma negociação em que o sindicato delibere a supressão de algum direito legal para a categoria (ou apenas para seus associados), impõe-se reconhecer que só se admite uma redução de direito de um lado se houver, de outro, a concessão de uma contrapartida de valor equivalente.

Afinal, se não houvesse a troca (aceita-se perder um direito para ganhar outro), isso não poderia sequer ser chamado de negociação, já que o negócio jurídico tem, por essência, os elementos da comutatividade e do sinalagma: o direito perdido deve ser equivalente ao direito ou garantia conquistada.

Ora, se o sindicato negociar a perda de um direito sem receber, em contrapartida, um ganho equivalente em favor dos trabalhadores, por óbvio não houve negociação coletiva, mas fraude. Nesse sentido, qualquer negociação que venha a retirar direitos sem contrapartida equivalente (ou, segundo a doutrina do Direito do Trabalho, sem sinalagma) é passível de controle jurisdicional por vício de nulidade.

A este propósito, e mesmo que este ponto esteja fora do objeto deste artigo, vale ressaltar que esta constatação se aplica igualmente a qualquer negociação individual entre empregado e empregador. Qualquer negócio entre empregados e empregado que suprima direitos trabalhistas sem 
garantia de receber, em troca, outros direitos de valor equivalente, não é negociação e deve ser objeto de controle judicial.

\section{A Reforma Trabalhista não tem como suprimir direitos e garantias constitucionais}

Para além disso, ainda que o sindicato pudesse negociar redução (ou melhore, a não-aplicação) de direitos previstos em lei a todos os trabalhadores abarcados pela categoria profissional representada pelo sindicato, não é possível conceber que os novos comandos normativos previstos pela Reforma Trabalhista ou pela Lei de Terceirização afrontem, manifestamente, os pilares que sustentam a defesa dos trabalhadores, terceirizados ou não, consignados pela Constituição Federal, que prescreve em seu artigo $7^{\circ}$ as garantias mínimas atribuídas aos trabalhadores.

Logo, quando da interpretação e aplicação das normas, é imprescindível que estas estejam em consonância com os direitos e garantias fundamentais do trabalhador, sob pena de ineficácia e declaração de sua inconstitucionalidade.

Ou seja, ainda que se possa imaginar que um sindicato possa, por negociação, determinar a não-aplicação de direitos previstos em lei a toda uma categoria profissional (e não apenas a seus associados), essa supressão jamais poderá ter por objeto os direitos e garantias previstos nos dispositivos constitucionais.

\section{Considerações finais}

Ora, se a terceirização, da maneira como já vinha sendo concebida, já trazia diversas preocupações para os empregados terceirizados nas atividades-meio, principalmente quanto às condições de trabalho e ao cumprimento das obrigações trabalhistas, com a abertura das possibilidades de terceirização estabelecidas pela Lei n. 13.429/2017, o Direito do Trabalho, que deve assegurar proteção àqueles que já são frágeis pela própria posição que ocupam na relação de trabalho, estaria comprometido quanto à sua finalidade.

A possibilidade de se terceirizar atividade-fim vai de encontro à promoção do desenvolvimento eficaz das relações laborais, reforçando a desigualdade entre os sujeitos envolvidos, que já é intrínseca à relação de trabalho. Ademais, tal prática ensejaria a deturpação do propósito para o 
qual a terceirização teria sido, teoricamente, criada: permitir que o empresário tomador de serviços concentre esforços exclusivamente nas atividades típicas de sua empresa.

Por outro lado, tratar trabalhadores que atuam na mesma empresa, de forma diferente, uns sendo contratados diretamente, outros mediante terceirização, em tese, afronta diretamente o princípio da isonomia ou do tratamento isonômico, direito fundamental previsto no artigo 70, XXXII, da Constituição.16 Algo superado nos termos da Súmula 331 do TST e da nova redação dada à CLT pela Lei n. 13.429/2017.

A Reforma Trabalhista, por sua vez, de modo infeliz, permite a redução ainda mais acentuada das normas protetivas do trabalho, manifestamente confrontando os preceitos constitucionais, eis que assegura às partes envolvidas na relação de trabalho a ampliação do poder de negociação, até mesmo no que concerne às normas coletivas, o que pode, certamente, degradar ainda mais as condições de trabalho e comprometer a remuneração dos trabalhadores como um tudo, em especial dos terceirizados.

Com a inauguração de novas possibilidades de terceirização, o desrespeito aos direitos sociotrabalhistas, como a ampla proteção do salário, será ainda maior. A terceirização, agora, é apresentada em uma forma ainda mais recrudescida, com tratamento ainda mais discriminatório, já que até mesmo aqueles que trabalharem nas atividades-fim da empresa estarão sujeitos a serem terceirizados.

A terceirização permite à tomadora promover a redução de seus custos. Em termos econômicos, a transferência da força de trabalho a outras pessoas jurídicas só faria sentido para a tomadora se houvesse essa redução de custos, de modo que os trabalhadores terceirizados recebam remuneração necessariamente inferior à dos trabalhadores nãoterceirizados. Em caso de equivalência na remuneração, por óbvio não compensaria ao empresário transformar o quadro de empregados em contratados de prestadoras terceirizadas.

Resta patente, portanto, que a terceirização favorece a precarização do trabalho, vez que, por meio dela, é possível relativizar os princípios e normas protetivas do trabalhador e da própria valorização do trabalho. Logo,

\footnotetext{
${ }^{16}$ Art. 70, CF: "São direitos dos trabalhadores urbanos e rurais, além de outros que visem à melhoria de sua condição social: XXXII - proibição de distinção entre trabalho manual, técnico e intelectual ou entre os profissionais respectivos;"
} 
o empregado terceirizado é colocado numa posição ainda mais vulnerável, em face do livre deslocamento de quaisquer atividades para sua realização por meio de terceiros, o que ensejaria a possibilidade de remunerar todos os trabalhadores da cadeia produtiva com salários abaixo daqueles que seriam devidos aos empregados da tomadora de serviços. Com o tempo, e justamente para reduzir seus custos, os empregadores tenderão a substituir todos os seus empregados por prestadores de serviços terceirizados.

Na prática, porém, a terceirização de atividade-fim se revela inócua para essa finalidade, eis que o sistema protetivo trabalhista vigente, estabelecido na Constituição Federal, não deve ser afastado pela aplicação da Lei $n$. 13.429/2017, de modo que os trabalhadores terceirizados que vierem a exercer atividade-fim da tomadora deverão ser representados e protegidos pelo único sindicato da categoria, estendendo-se a proteção sindical a todos os trabalhadores, inclusive aos terceirizados. Deve ser mantida, portanto, a correspondência de remuneração e demais direitos em relação aos profissionais dos quadros da tomadora, visto que integram a mesma categoria profissional e se encontram, por este motivo, sob a proteção do mesmo sindicato, eliminando por completo eventual vantagem econômica buscada pelo empresário na terceirização de sua atividade-fim.

Do mesmo modo, verifica-se que a investida da Reforma Trabalhista sobre o Direito do Trabalho, visando à precarização deste, ainda pode ser resistida, seja porque os sindicatos não têm poderes para negociar supressão de direitos legais em favor de trabalhadores que não sejam seus associados, seja porque a supressão de direitos imporia, em troca, algum benefício de valor equivalente ao direito suprimido, algo que pode e deve ser submetido a controle de legalidade, seja porque negociação coletiva alguma teria o condão de suprimir direitos constitucionalmente assegurados.

\section{Referências}

ALVES, Giovanni. Trabalho e Mundialização do Capital: A nova degradação do trabalho na era da globalização. 2a ed. Londrina: Práxis, 1999.

ANTUNES, Ricardo. Os modos de ser da informalidade: rumo a uma nova era da precarização estrutural do trabalho? Serviço Social \& Sociedade, n. 107, São Paulo, jul./set., p. 405-419, 2011. Disponível em: <http://www.scielo.br/scielo.php?script=sci_arttext\&pid=S0101$66282011000300002>$. Acesso em 15 ago. 2017. 
BATISTA, Eraldo Leme. Terceirização no Brasil e suas Implicações para os Trabalhadores. Campinas: Pontes, 2010.

BRASIL. Câmara dos Deputados. Redação Final Projeto de Lei no 6.787-B de 2016. Altera a Consolidação das Leis do Trabalho (CLT), aprovada pelo Decreto-Lei $n$ 5.452, de 10 de maio de 1943, e as Leis n. 6.019, de 3 de janeiro de 1974, n. 8.036, de 11 de maio de 1990, e n. 8.212, de 24 de julho de 1991, a fim de adequar a legislação às novas relações de trabalho. Disponível em: <http://www.camara.gov.br/proposicoesWeb/prop_mostrarintegra?codteor=1550 864\&filename=Tramitacao-PL+6787/2016>. Acesso em 15 ago. 2017.

BRASIL, Constituição (1988). Constituição da República Federativa do Brasil. Brasília, DF: Senado, 1988.

BRASI, Decreto-Lei n. ㅇ 5.452, de 1ㅇde maio de 1943 CLT. Aprova a Consolidação das Leis do Trabalho. Brasília, DF: 1943.

BRASIL, Lei no 13.429, de 31 de março de 2017. Altera dispositivos da Lei no 6.019, de 3 de janeiro de 1974, que dispõe sobre o trabalho temporário nas empresas urbanas e dá outras providências; e dispõe sobre as relações de trabalho na empresa de prestação de serviços a terceiros. Disponível em: <http://www.planalto.gov.br/ccivil_03/_ato2015-2018/2017/lei/L13429.htm>. Acesso em: 15 ago. 2017.

BRASIL. Tribunal Superior do Trabalho. Súmula n. 331. Contrato de Prestação de Serviços. Disponível em: <http://www3.tst.jus.br/jurisprudencia/Sumulas_com_indice/Sumulas_Ind_301_3 50.html>. Acesso em: 15 ago. 2017

COSTA, Márcia da Silva. Terceirização/Parceria e suas implicações no âmbito jurídico-sindical, Revista de Administração de Empresas, São Paulo, v. 34, n. 1, p. 611, jan./fev. 1994. Disponível em: <http://www.scielo.br/scielo.php?pid=S0034$75901994000100002 \&$ script=sci_arttext>. Acesso em: 15 ago. 2017.

DRUCK, Graça; FRANCO, Tânia. A Terceirização no Brasil: velho e novo fenômeno, Laborel, v. IV, p. 83-94, 2008. Disponível em: <http://laboreal.up.pt/pt/articles/aterceirizacao-no-brasil-velho-e-novo-fenomeno>. Acesso em: 15 ago. 2017.

DRUCK, Graça. Terceirização: (des)fordizando a fábrica - um estudo do complexo petroquímico da Bahia. Tese de doutorado. Unicamp, Mimeo, 1995. Disponível em: <http://repositorio.unicamp.br/jspui/handle/REPOSIP/280279>. Acesso em: 15 ago. 2017.

KREMER, Antônio; FARIA, José Henrique. Reestruturação produtiva e precarização do trabalho: o mundo do trabalho em transformação. R. Adm., São Paulo, v. 40, n. 
3, p. 266-279, jul./ago./set. 2005. Disponível em: <http://www.redalyc.org/articulo.oa?id=223417392005>. Acesso em: 15 ago. 2017.

MAIOR, Jorge Luiz Souto. Trabalho Descentralizado - Terceirização não pode ser usada para burlar direitos. Revista Anamatra, 2004. Disponível em: <https://www.anamatra.org.br/artigos/896-trabalho-descentralizado-

012890242331559065?highlight=WyJzb3VObylsIm1haW9yliwic291dG8gbWFpb3lix $\mathrm{Q}==$ >. Acesso em: 15 ago. 2017.

MATTOSO, Jorge. O Brasil desempregado. São Paulo: Fundação Perseu Abramo, 1999.

OLIVEIRA, Fernanda Sousa. Terceirização e Flexibilização das Normas Trabalhistas. Revista Prolegómenos - Derechos y Valores, v. XVI, n. 31, p. 189-201, jan. /jun. 2013. Disponível em: <http://www.redalyc.org/articulo.oa?id=87628085011>. Acesso em: 15 ago. 2017.

PINHEIRO-MACHADO, Rosana. China-Paraguai-Brasil uma rota para pensar a economia informal. Revista Brasileira de Ciências Sociais, São Paulo, v. 23, n. 67, p. 117-133, jun. 2008. Disponível em: $<$ http://www.scielo.br/scielo.php?script=sci_arttext\&pid=S010269092008000200009\&lng=pt\&nrm=iso>. Acesso em: 15 ago. 2017.

VIANA, Márcio Túlio. As várias faces da terceirização. Rev. Fac. Direito UFMG, Belo Horizonte, n. 54, p. 141-155, jan./jun. 2009. Disponível em: <http://www.direito.ufmg.br/revista/index.php/revista/article/view/96/90>. Acesso em: 15 ago. 2017. 